\title{
The Conservation Reserve Program: Planting for the Future
}

Proceedings are now available from a scientific and technical forum held to review ongoing and planned research, identify lessons learned, and determine future research needs for the purpose of developing a rigorous scientific basis for future CRP policy discussions.

Of 36 million acres currently in the Conservation Reserve Program (CRP) nationwide, over 28 million acres of CRP contracts will expire between 2007 and 2010. With this in mind, the U.S. Department of Agriculture (USDA) Farm Service Agency (FSA), with support from the U.S. Geological Survey, Fort Collins Science Center, held a 3-day symposium in June 2004 on the future of the CRP.

The symposium, The Conservation Reserve Program: Planting for the Future, provided a forum to review scientific analyses, introduce ongoing and planned research, exchange views and objectives, explore lessons learned, and define needs to enhance program performance. Major themes included the need to quantify and communicate the CRP's environmental and economic effects, appropriate management of CRP land, and the program's impact on rural economies, and develop State and Federal partnerships to improve the USDA's abil- ity to meet regional and national agricultural and environmental needs.

The overall aim of the conference was to provide science-based analysis to inform producers, legislators, budget overseers, agency personnel, and other decisionmakers on how best to manage the CRP, minimize taxpayer costs, and maximize agricultural and environmental benefits.

Symposium proceedings include 29 papers supplemented with moderator comments and appendixes. The proceedings address the social, economic, and ecological effects of the CRP; identify current and needed research; and offer recommendations for continued refinement and management of the program.

Presenters included representatives of the following agencies, organizations, and institutions:

American Farm Bureau Federation

American Seed Trade Association

Colorado Division of Wildlife

Ducks Unlimited

Environmental Defense

International Association of Fish and Wildlife Agencies

Kansas Department of Wildlife and Parks

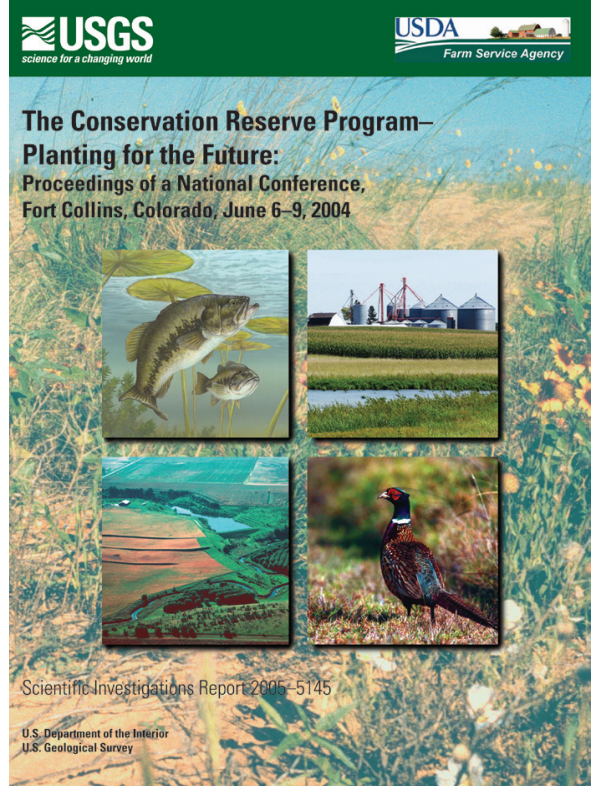

Mississippi State University National Cattlemen's Beef

Association

National Grain and Feed Association Oklahoma State University

Pheasants Forever

Soil and Water Conservation Society University of Illinois

USDA, Economic Research Service

USDA, Farm Service Agency

USDA, Natural Resources

Conservation Service

U.S. Fish and Wildlife Service

U.S. Geological Survey

Wildlife Management Institute

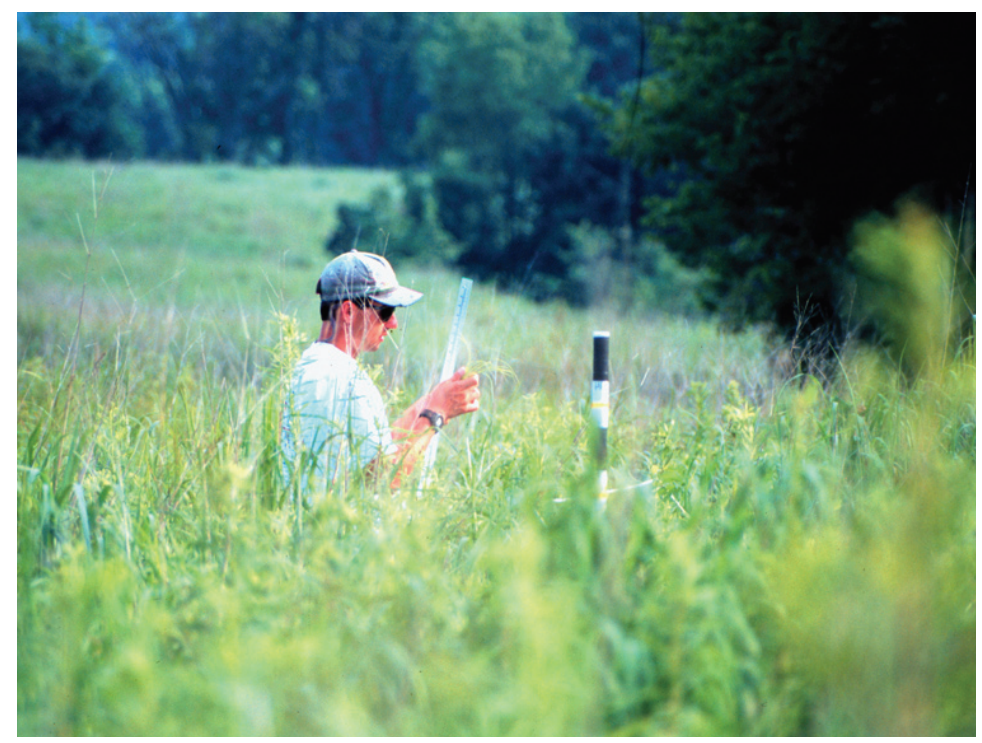

\begin{tabular}{|c|c|}
\hline \multicolumn{2}{|c|}{$\begin{array}{l}\text { Conference proceedings are available online at } \\
\text { http://www.fsa.usda.gov/pas/crpconf.asp } \\
\text { and } \\
\text { http://www.fort.usgs.gov/products/publications/ } \\
21490 / 21490 . a s p\end{array}$} \\
\hline \multicolumn{2}{|c|}{ For more information, contact } \\
\hline $\begin{array}{l}\text { Skip Hyberg } \\
\text { USDA Farm Service Agency } \\
3728 \text { South Agriculture Building } \\
1400 \text { Independence Ave. SW } \\
\text { Washington, DC 20250-0506 } \\
\text { Tel. 202.720.9222 } \\
\text { Skip.Hyberg@wdc.usda.gov }\end{array}$ & $\begin{array}{l}\text { Art Allen } \\
\text { USGS Fort Collins Science Center } \\
2150 \text { Centre Avenue } \\
\text { Building C } \\
\text { Fort Collins, C0 80526-8118 } \\
\text { Tel.970.226.9312 } \\
\text { Arthur_Allen@usgs.gov }\end{array}$ \\
\hline
\end{tabular}

